\title{
ON A SMALL COLLECTION OF DECAPOD CRUSTACEANS (MALACOSTRACA, DECAPODA) FROM THE GALAPAGOS ISLANDS, COLLECTED BY P. H. VERCAMMEN-GRAND-JEAN, IN 1964
}

\author{
BY \\ MICHEL E. HENDRICKX ${ }^{1}$ ) \\ Laboratorio de Invertebrados Bentónicos, Unidad Académica Mazatlán, Instituto de Ciencias del \\ Mar y Limnología, Universidad Nacional Autónoma de México, P.O. Box 811, Mazatlán, \\ Sinaloa 82000, Mexico
}

\begin{abstract}
A small collection of unidentified decapod crustaceans from the island Santa Cruz de las Galápagos ("Indefatigable"), Galapagos Archipelago, Ecuador, located in the holdings of the Royal Belgian Institute of Natural Sciences, Brussels (RBINS), Belgium, was examined. A total of 63 lots containing 21 species was found, all collected in January and February, 1964, near the Darwin Station. All species had previously been reported from the Galápagos Archipelago and represent about $9.3 \%$ of the marine, shallow-water decapod fauna reported for the islands.
\end{abstract}

\section{RÉSUMÉ}

Une petite collection de crustacés décapodes non identifiés de l'île Santa Cruz de las Galápagos ("Indefatigable" Island), archipel des Galapagos, en Équateur, localisée à l'Institut Royal des Sciences Naturelles de Bruxelles (IRScNB), Belgique, a été examinée. Un total de 63 lots, contenant 21 espèces ont été trouvés, toutes récoltées en janvier et février 1964, près de la station Darwin. Toutes les espèces avaient déjà été signalées dans l'archipel des Galapagos et elles représentent environ $9,3 \%$ de la faune marine des décapodes des eaux peu profondes signalé pour ces îles.

\section{INTRODUCTION AND MATERIAL}

For their peculiar location and isolation from the American continent, the Galapagos Islands are among the most interesting areas in the eastern Pacific for the study of marine and terrestrial fauna. Marine invertebrates have been intensively studied thanks to expeditions that repeatedly visited the islands. In the first half of the 20th century, large collections of specimens were obtained from

1) e-mail: michel@ola.icmyl.unam.mx 
different habitats and studied in several institutions, mostly in the United States of America. Decapod crustaceans are not the exception, and several significant contributions that include Galapagos specimens, essentially those collected during the "Velero III" visits to the islands were published.

The study of Galapagos decapod crustaceans is greatly facilitated using the classical contributions by Garth (1946a, 1958a, b) on Brachyura, by Holthuis on Palaemonidae (1951, 1952), and by Haig (1960) on Porcellanidae. These authors entirely or partly based their study on Galapagos material. Other, more recent contributions, dealing with Galapagos species, include (chronologically) the review of the genus Alpheus in the East Pacific by Kim \& Abele (1988), a report on the caridean and stenopodidean shrimps of the Galapagos by Wicksten (1991), on Porcellanidae by Harvey (1991), on Brachyura by Garth (1991), and on anchialine species by Iliffe (1991). More recently, a guide to common crustaceans of the Galapagos was made available by Hickman \& Zimmerman (2000).

The collection of marine decapod crustaceans on which this report is based is part of the holdings of the Royal Belgian Institute of Natural Sciences (RBINS), Brussels (General Inventory, 23611), and had remained untouched since it was donated by P. H. Vercammen-Grand-Jean, University of California, San Francisco, in October 1966, together with additional specimens of other invertebrates and vertebrates. The material, except one lot, was collected in the rocky intertidal area, close to the Darwin Station, on Santa Cruz de las Galápagos ("Indefatigable") Island, between 1 and 20 February 1964. One lot of hermit crabs was collected on 29 January [1964], at "Bodega Station". No details related to the exact localities where individual samples were collected are available. Nevertheless, due to the fact that the number of large collections obtained from the islands in the second half of the $20^{\text {th }}$ century has consistently decreased over the years, and that recent observations indicate that the composition of the marine fauna might have switched due to climatic changes (see Wicksten, 1991; Hickman \& Zimmerman, 2000), it is considered important to report on this material.

\section{SYSTEMATIC SECTION}

The collection examined herein includes a total of 63 lots corresponding to five species of Caridea (plus an unidentified, damaged specimen of Alpheus), five species of Anomura, and 11 species of Brachyura. From the composition of the collection it can be deduced that the material collected was among the most accessible and abundant in the area, and it appears that little effort was made to obtain a more diverse collection. Due to the fragility of some specimens or superficial damages, it was not always possible to determine the sex of the material 
examined. Abbreviations are: CL, carapace length; $\mathrm{CW}$, carapace width; SL, shield length. All lots except one have the same collection data and samples of the same species were pooled for cataloguing in the RBINS Invertebrates (INV) collection.

\section{CARIDEA}

\section{ALPHEIDAE}

Alpheus malleator Dana, 1852. Two males (CL, 14.4-15.5 mm) and two ovigerous females (CL, 11.8-12-1 mm) (RBINS-INV.78312).

Alpheus canalis Kim \& Abele, 1988. One male (CL, 11.5 mm) (RBINS-INV.78313).

Alpheus paracrinitus Miers, 1881. One unsexed specimen (CL, ca $5 \mathrm{~mm}$ ) (RBINS-INV.78314).

Alpheus cf. longinquus Kim \& Abele, 1988. One unsexed specimen (CL, $5.6 \mathrm{~mm}$ ) (RBINSINV.78315).

\section{HIPPOLYTIDAE}

Lysmata galapagensis Schmitt, 1924. Two unsexed specimens (CL, 4.3-6.4 mm) (RBINSINV.78316).

ANOMURA

\section{PORCELLANIDAE}

Petrolisthes edwardsii (de Saussure, 1853). Two males (CW13.3-18.4 mm) and one ovigerous female (CW, $12.3 \mathrm{~mm}$ ) (RBINS-INV.78317).

Petrolisthes marginatus Stimpson, 1858. One male $(\mathrm{CW}, 11.2 \mathrm{~mm})$ and one ovigerous female $(\mathrm{CW}$, $9.9 \mathrm{~mm}$ ) (RBINS-78318).

Petrolisthes polymitus Glassell, 1937. One ovigerous female (CW, $5.2 \mathrm{~mm})$ (RBINS-INV.78319).

\section{COENOBITIDAE}

Coenobita compressus Guérin, 1831. Eight males (SL, 11.8-18.3 mm), one female (SL, $13.3 \mathrm{~mm}$ ), and three ovigerous females (SL, 12.0-16.6 mm) (RBINS-INV.78320).

\section{DIOGENIDAE}

Calcinus explorator Boone, 1931. Twenty-two males (SL, 2.3-8.2 mm), five females (SL, 2.4$4.6 \mathrm{~mm}$ ), seven ovigerous females (SL, 2.4-4.2 mm), 16 juveniles, and 11 unsexed specimens (RBINS-INV.78321). Two males (SL, 7.5-8.2 mm) (RBINS-78322) collected at "Bodega Station". 


\section{BRACHYURA}

\section{MAJIDAE}

Mithraculus nodosus (Bell, 1835). Two males (CW, 12.7-23.7 mm), two females (CW, 13.5$17.3 \mathrm{~mm}$ ), one ovigerous female (CW, $19.0 \mathrm{~mm}$ ), and one young specimen (RBINS-INV.78323). Teleophrys cristulipes Stimpson, 1860. Two males (CW, 11.3-12.4 mm) (RBINS-INV.78324). Herbstia edwardsii Bell, 1835. One ovigerous female (CW, $8.8 \mathrm{~mm}$ ) (RBINS-INV.78325).

\section{DAIRIDAE}

Daira americana (Stimpson, 1860). Three females (CW, 19.1-24.5 mm) (RBINS-INV.78326).

\section{ERIPHIDAE}

Eriphia granulosa A. Milne-Edwards, 1880. Two males (CW, 8.9-13.6 mm) and one ovigerous female (CL, $13.9 \mathrm{~mm}$ ) (RBINS-INV.78329).

\section{MENIPPIDAE}

Menippe obtusa Stimpson, 1860. Two ovigerous females (CW, 54.0-67.5 mm) (RBINS-INV.78331).

\section{OZIIDAE}

Ozius tenuidactylus (Lockington, 1877). Two males (CW, 8.7-9.0 mm) and one ovigerous female (CL, 9.9 mm) (RBINS-INV.78330).

\section{XANTHIDAE}

Xanthodius cooksoni (Miers, 1877). Four males (CW, 9.7-16.5 mm) and two ovigerous females (CW, 11.7-15.4 mm) (RBINS-INV.78327).

Cataleptodius snodgrassi (Rathbun, 1902). One female (CW, $12.4 \mathrm{~mm}$ ) and one ovigerous female (CW, $16.3 \mathrm{~mm}$ ) (RBINS-INV.78328).

\section{GRAPSIDAE}

Pachygrapsus transversus (Gibes, 1850). One male (CW, $9.1 \mathrm{~mm}$ ) (RBINS-INV.78332).

\section{OCYPODIDAE}

Uca galapagensis galapagensis Rathbun, 1902. Three males (CW, 13.9-16.9 mm) (RBINSINV.78333). 


\section{DISCUSSION}

As noted earlier, the composition of the collection examined herein reflects a very superficial sampling procedure in a rocky intertidal habitat. Data available in literature indicate that most of the species collected were and probably still are among the most commonly found within their respective families or genera in the Galapagos Islands intertidal zone. Our recent (i.e., post 1964) knowledge of the Galapagos Islands decapod crustacean fauna has changed substantially. New species have been described and others have been reported for the islands. There is, however, no reason to believe that these additional species were not already present when the samples examined herein were collected.

The genus Alpheus is represented on the islands by as many as 19 or 20 species (the latter figure, if A. chilensis Coutière, 1902, is included) (see Kim \& Abele, 1988; Wicksten, 1991; Wicksten \& Hendrickx, 2003), and only three were found in the samples. Of the three species of Lysmata reported (see Wicksten, 1991; Hickman \& Zimmerman, 2000) only one, probably the most common, was found. Altogether, 60 species of Caridea and Stenopodidea occurring in less than $50 \mathrm{~m}$ depth have been recorded for the Galapagos (Wicksten, 1991, 1999), of which only four (7\%) were collected during this survey. Iliffe (1991) reports one species of anchialine Caridea from the islands, but that specific habitat was not sampled during this survey. The Porcellanidae of the Galapagos include 12 species (Haig, 1960; Harvey, 1991; Hendrickx \& Harvey, 1999), eight in the genus Petrolisthes, of which three were collected. The hermit crabs include at least 12 species (see Hickman \& Zimmerman, 2000; Hendrickx \& Harvey, 1999), and only the two most obvious and abundant species were collected, one terrestrial (Coenobita compressus) and one intertidal (Calcinus explorator). The shallow water Hippoidea were not represented in the samples, although two species have been reported for the islands (see Hendrickx \& Harvey, 1999), but they are typical of sandy beaches and the subtidal. Altogether, shallow water Anomura are represented in the Galapagos by at least 26 species of which only five (19\%) were captured. Finally, of the 120 species of Brachyura reported by Garth $(1946 b, 1991)$ for the islands, only $11(9 \%)$ were collected.

There were no specimens of Dendrobranchiata, Palinura, or Thalassinidea in the material examined. The islands' marine, shallow-water fauna includes five, two, and five species for each group (see Hendrickx, 1995a, b, c; Kensley \& Hickman, 2001; Wicksten \& Hendrickx, 2003), respectively. Very few species, however, are only exceptionally found in rocky tidal pools during the lowest tides.

All groups included, the shallow-water marine and anchialine decapod crustacean fauna of the Galapagos Islands includes 224 species, of which only 21 (9.3\%) were collected by P. H. Vercammen-Grand-Jean. Hickman \& Zimmerman 
(2000) consider 171 species in their guide, the "most likely to be encountered by scuba diving, snorkeling, or tide pooling" [sic]. Although this figure includes a significant proportion of species not or not easily accessible in the intertidal zone, the collection examined in the present contribution (21 species, or $12.3 \%$ ) must still be considered very poor.

\section{ACKNOWLEDGEMENTS}

I thank Frank Fiers (RBINS) for calling my attention to this collection of decapod crustaceans from the Galapagos, Thierry Backeljau (RBINS), Head of the Recent Invertebrates Dept., and the Institut Royal des Sciences Naturelles de Belgique (RBINS) for the facilities provided during my stay. This study was supported by DGAPA, PASPA, UNAM, during a sabbatical leave of MEH at the RBINS. The final edition was prepared by Mercedes Cordero.

\section{REFERENCES}

GARTH, J. S., 1946a. Littoral brachyuran fauna of the Galapagos Archipelago. Allan Hancock Pacific Exped., 5 (10): 341-601.

— - 1946b. Distribution study of Galapagos Brachyura. Allan Hancock Pacific Exped., 5 (11): 603-648.

— - 1958a. Brachyura of the Pacific coast of America; Oxyrhyncha. Text. Allan Hancock Pacific Exped., 21 (1): 1-499.

— - 1958b. Brachyura of the Pacific coast of America; Oxyrhyncha. Tables and plates. Allan Hancock Pacific Exped., 21 (2): 501-854.

— - 1991. Taxonomy, distribution and ecology of Galapagos Brachyura. In: M. J. JAMES (ed.), Galapagos marine invertebrates. Taxonomy, biogeography and evolution in Darwin's Islands: 123-145. (Plenum Press, New York).

Haig, J., 1960. The Porcellanidae (Crustacea Anomura) of the eastern Pacific. Allan Hancock Pacific Exped., 24: 1-440.

HARVEY, A. W., 1991. Biogeographic patterns of the Galapagos porcelain crab fauna. In: M. J. JAMES (ed.), Galapagos marine invertebrates. Taxonomy, biogeography and evolution in Darwin's Islands: 157-172. (Plenum Press, New York).

HendrickX, M. E., 1995a. Camarones. In: W. Fischer, F. Krupp, W. Schneider, C. Sommer, K. E. CARPEnter \& V. H. NiEM (eds.), Guía FAO para la identificación de especies para los fines de la pesca. Pacífico centro-oriental, 1, Plantas e Invertebrados: 417537. (FAO, Rome).

— - 1995b. Langostas (langostas espinosas, bogavantes, cigarras y zapateras, langostas de lodo, etc.). In: W. Fischer, F. Krupp, W. Schneider, C. Sommer, K. E. Carpenter \& V. H. NIEM (eds.), Guía FAO para la identificación de especies para los fines de la pesca. Pacífico centro-oriental, 1, Plantas e invertebrados: 383-416. (FAO, Rome).

— - 1995c. Checklist of lobster-like decapod crustaceans (Crustacea: Decapoda: Thalassinidea, Astacidea and Palinuridea) from the eastern tropical Pacific. An. Inst. Biol. UNAM, 66 (2): 153-165.

HENDRICKX, M. E. \& A. W. HARVEY, 1999. Checklist of anomuran crabs (Crustacea: Decapoda) from the eastern tropical Pacific. Belgian Journ. Zool., 129 (2): 327-352. 
Hickman, C. P., JR. \& T. L. Zimmerman, 2000. A field guide to crustaceans of Galapagos. An illustrated guidebook to the common barnacles, shrimps, lobsters, and crabs of the Galapagos Islands: 1-154. (Sugar Spring Press, Lexington, Virginia).

Holthuis, L. B., 1951. A general revision of the Palaemonidae (Crustacea Decapoda Natantia) of the Americas. I. The subfamilies Euryrhynchinae and Pontoniinae. Occas. Papers Allan Hancock Found., 11: 1-332.

— - 1952. A general revision of the Palaemonidae (Crustacea Decapoda Natantia) of the Americas. II. The subfamily Palaemoninae. Occas. Papers Allan Hancock Found., 12: 1-396.

ILIFFE, T. M., 1991. Anchialine fauna of the Galapagos islands. In: M. J. JAMES (ed.), Galapagos marine invertebrates. Taxonomy, biogeography and evolution in Darwin's Islands: 209-231. (Plenum Press, New York).

Kensley, B. \& C. P. Hickman, JR., 2001. A new species of Calaxius Sakai \& de Saint Laurent, 1989, from the Galapagos Islands (Crustacea: Axiidae). Proc. biol. Soc. Washington, 114 (2): 484-488.

Kim, W. \& L. G. Abele, 1988. The snapping shrimp genus Alpheus from the eastern Pacific (Decapoda: Caridea: Alpheidae). Smithson. Contrib. Zool., 454: 1-119.

WiCKSTEN, M. K., 1991. Caridean and stenopodid shrimps of the Galápagos Islands. In: M. J. JAMES (ed.), Galapagos marine invertebrates. Taxonomy, biogeography and evolution in Darwin's islands: 147-156. (Plenum Press, New York).

—, 1999. A new genus and species of alpheid shrimp (Caridea: Alpheidae) from the Galapagos Islands. Crust. Res., 28: 104-111.

Wicksten, M. K. \& M. E. HendRickX, 2003. An updated checklist of benthic marine and brackish water penaeoid and caridean shrimps (Decapoda: Penaoidea, Caridea) from the eastern tropical Pacific. In: M. E. HENDRICKX (ed.), Contributions to the study of east Pacific crustaceans [Contribuciones al estudio de los Crustáceos del Pacífico Este], 2: 49-76. (Instituto de Ciencias del Mar y Limnología, UNAM, Mexico).

First received 7 January 2010.

Final version accepted 8 January 2010. 